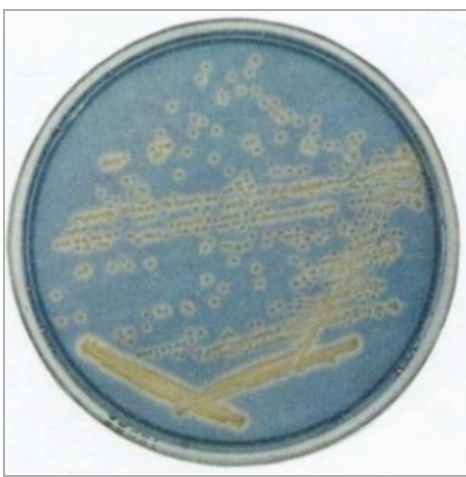

JUN 19, 2017

\section{open $\odot$ Access}

DOI:

dx.doi.org/10.17504/protocol s.io.idvca66

Protocol Citation: Dr. Steven Wilhelm 2017. Chrome Azural $S$ (CAS) Plate Assay for IronBinding Compounds. protocols.io

https://dx.doi.org/10.17504/p rotocols. io.idvca66

License: This is an open access protocol distributed under the terms of the Creative Commons Attribution License, which permits unrestricted use, distribution, and reproduction in any medium, provided the original author and source are credited

Protocol status: Working

Created: Jun 09, 2017

Last Modified: Mar 21, 2018

PROTOCOL integer ID:

6293

\section{(3) Chrome Azural S (CAS) Plate Assay for Iron-Binding Compounds}

\author{
Dr. Steven Wilhelm
}

The Aquatic Microbial Ecology Research Group - AMERG (The Buchan, Zinser and Wilhelm labs)

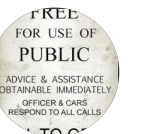

Steven W Wilhelm

The University of Tennessee, Knoxville

\section{ABSTRACT}

Please contact Dr. Steven Wilhelm (wilhelm@utk.edu) for additional information regarding this protocol.

Modified from Schwyn, B. \& Neilands, J. B. Universal chemical assay for the detection and determination of siderophores. Anal Biochem, 160:147-156 (1987).

\section{MATERIALS}

\section{STEP MATERIALS}

$\$ 8$ Piperazine anhydrous Contributed by users

89 Iron(III) chloride hexahydrate Merck MilliporeSigma (Sigma-Aldrich) Catald \#44944

89 CTAB (Hexadecyltrimethylamm onium bromide) BBI Biotech Catalog \#CB0108-100g

8 Piperazine anhydrous Contributed by users

88 Iron(III) chloride hexahydrate Merck MilliporeSigma (Sigma-Aldrich) Catald \#44944

88 CTAB (Hexadecyltrimethylamm onium bromide) BBI Biotech Catalog \#CB0108-100g

\title{
Assay Solution Preparation
}

Take $6 \mathrm{~mL} 10 \mathrm{mM}$ CTAB (HDTMA) stock and mix with $40 \mathrm{~mL}$ Milli-Q $\mathrm{H}_{2} \mathrm{O}$ 
$2 \quad$ Mix $1.5 \mathrm{~mL} \mathrm{FeCl}_{3}-\mathrm{HCl}$ stock $\left(1 \mathrm{mM} \mathrm{FeCl}_{3}\right.$ dissolved in $10 \mathrm{mM} \mathrm{HCl}$ ) with $7.5 \mathrm{~mL} 2 \mathrm{mM}$ CAS dye stock

Q8 Iron(III) chloride hexahydrate Merck MilliporeSigma (Sigma-Aldrich) Catalog \#44944

3 Slowly add Fe-CAS mixture to CTAB solution while stirring

4 Add $6.5 \mathrm{~mL}$ of $12 \mathrm{~N} \mathrm{HCl}$ slowly to $25 \mathrm{~mL}$ Milli-Q $\mathrm{H}_{2} \mathrm{O}$

$5 \quad$ Add $4.3 \mathrm{~g}$ anhydrous piperazine to the acid solution

I $4.3 \mathrm{~g}$

88 Piperazine anhydrous Contributed by users

6 Mix the piperazine acid solution slowly into the Fe-CAS*CTAB solution

7 Bring CAS solution to $100 \mathrm{~mL}$ final volume

\ $100 \mathrm{~mL}$

8 Add enough 5-sulfosalicyclic acid to get $4 \mathrm{mM}$ final concentration

\section{Assay Part I}

9 Add $60.5 \mathrm{mg}$ of $2 \mathrm{mM}$ CAS dye to $50 \mathrm{~mL}$ Milli-Q $\mathrm{H}_{2} \mathrm{O}$ 
10 Add $10 \mathrm{~mL} \mathrm{FeCl}_{3}$ solution

\section{\ $10 \mathrm{~mL}$}

11 Dissolve $73 \mathrm{mg}$ of $10 \mathrm{mM} \mathrm{CTAB}$ (HDTMA) in $40 \mathrm{~mL}$ Milli-Q $\mathrm{H}_{2} \mathrm{O}$

12 Mix the two solutions together

13 Bring solution to $1 \mathrm{~L}$ with Milli-Q $\mathrm{H}_{2} \mathrm{O}$

\section{\1L}

14 Autoclave at $121^{\circ} \mathrm{C}$ for $20 \mathrm{~min}$

\section{Assay Part II}

15 Make medium depending on the type of microorganism that you are trying to grow.

Note

For example, add ESAW-FE with casamino acids, peptone and agar for marine microorganisms.

16 Autoclave medium at $121^{\circ} \mathrm{C}$ for $20 \mathrm{~min}$ 
17 Once both part I and part II are cooled $\left(55^{\circ} \mathrm{C}\right)$, mix the two solutions together and pour plates.

18 Incubate plates according to the microorganism. Screen plates once colonies are grown: yellow halos $=$ siderophore and blue $=$ no siderophore 